| Faktor Penyebab KDRT

\title{
FAKTOR-FAKTOR PENYEBAB TERJADINYA KEKERASAN DALAM RUMAH TANGGA PADA SURVIVOR YANG DITANGANI OLEH LEMBAGA SAHABAT PEREMPUAN MAGELANG
}

\author{
Evi Tri Jayanthi ${ }^{1}$
}

\begin{abstract}
Abstrak
Penelitian ini bertujuan untuk mengetahui faktor-faktor penyebab terjadinya Kekerasan dalam rumah tangga pada survivor yang ditangani oleh Lembaga Sahabat Perempuan Magelang, bentuk-bentuk kekerasan yang dialami oleh survivor serta reaksi survivor terhadap kekerasan yang dialaminya. Untuk membedah kasus kekerasan tersebut, peneliti menggunakan teori yang relevan dengan permasalahan, yaitu dengan menggunakan teori konflik, fungsionalisme struktural dan feminisme.

Jenis penelitian yang digunakan adalah penelitian kualitatif deskriptif. Peneliti mengambil lokasi penelitian di Lembaga Sahabat Perempuan Magelang. Subyek Penelitian ini adalah tujuh survivor yang melapor ke Sahabat Perempuan antara tahun 2005-2008 serta seorang staf divisi Pengorganisasian dan Bantuan Hukum. Subyek penelitian tersebut diambil dengan menggunakan teknik purposive sampling. Dalam pengumpulan data, peneliti menggunakan teknik wawancara dan dokumentasi. Triangulasi sumber digunakan sebagai teknik dalam pemeriksaan keabsahan data. Langkah-langkah yang diambil dalam analisis data adalah reduksi data, unitasi dan kategorisasi, display data dan pengambilan kesimpulan.

Hasil penelitian menunjukkan bahwa faktor-faktor penyebab terjadinya kekerasan dalam rumah tangga pada survivor adalah perselingkuhan, masalah ekonomi, budaya patriarki, campur tangan pihak ketiga, bermain judi, dan perbedaan prinsip. Faktor utama yang menyebabkan kekerasan dalam rumah tangga adalah perselingkuhan yang dilakukan suami dengan perempuan lain. Bentuk-bentuk kekerasan yang dialami oleh survivor adalah kekerasan fisik (ditampar, dijambak, ditempeleng, diinjak-injak), kekerasan psikis (caci maki, ancaman), dan penelantaran rumah tangga. Beberapa survivor mengambil sikap diam atas kekerasan yang dialaminya. Hal ini dikarenakan mereka tidak mau terjadi peristiwa yang lebih parah lagi dan tidak menghendaki permasalahan semakin berlarut-larut. Selain bersikap diam, beberapa survivor bersikap melawan terhadap suami atas kekerasan yang menimpanya. Perlawanan tersebut sebagai upaya perlindungan atas serangan suami yang mengakibatkan luka fisik maupun nonfisik. Dengan demikian dapat dikatakan bahwa masih relevannya teori konflik, teori fungsionalisme struktural dan teori
\end{abstract}

${ }^{1}$ Penulis adalah alumni Program Studi Pendidikan Sosiologi, FISE, Universitas Negeri Yogyakarta 
| Evi Tri Jayanthi

feminisme dengan kenyataan yang ada di masyarakat, yakni dalam mengkaji kekerasan dalam rumah tangga.

Kata kunci: kekerasan dalam rumah tangga, survivor, advokasi perempuan.

\section{A. Pendahuluan}

Wacana mengenai kekerasan dalam rumah tangga (KDRT) telah menjadi isu global dan telah menjadi perhatian publik. Kekerasan dalam lingkup domestik ini menjadi tema ataupun topik penting yang diangkat dalam media massa maupun dalam seminarseminar. Fenomena akan adanya kekerasan domestik ini bagaikan fenomena gunung es, yang mana kasus yang tampak di permukaan tidak sebanyak dengan kasus yang terjadi sesungguhnya di lapangan.
Hal ini dikarenakan masalah dalam keluarga merupakan masalah privat dan tabu bila disebarluaskan.

Secara lebih khusus, Lembaga Sahabat Perempuan sebagai salah satu lembaga di Kabupaten Magelang yang menangani masalah kekerasan terhadap perempuan mencatat bahwa jumlah korban kekerasan terutama dalam lingkup rumah tangga juga mengalami peningkatan. Hal ini dapat dilihat dari tabel berikut:

Tabel 2: Data kasus KDRT yang ditangani

Lembaga Sahabat Perempuan Magelang

\begin{tabular}{|l|c|c|c|c|c|}
\hline & $\begin{array}{c}\text { Tahun } \\
2003\end{array}$ & $\begin{array}{c}\text { Tahun } \\
2004\end{array}$ & $\begin{array}{c}\text { Tahun } \\
2005\end{array}$ & $\begin{array}{c}\text { Tahun } \\
2006\end{array}$ & $\begin{array}{c}\text { Tahun } \\
2007\end{array}$ \\
\hline $\begin{array}{c}\text { Jumlah } \\
\text { Kasus }\end{array}$ & 14 kasus & 24 kasus & 35 kasus & 42 kasus & 49 kasus \\
\hline
\end{tabular}

Sumber: Dokumentasi Sahabat Perempuan tahun 2008.

Jumlah korban yang tercatat antara tahun 2003 sampai dengan 2007 ini hanya merupakan korban yang melapor atau meminta advokasi ke Lembaga Sahabat Perempuan Magelang.

Peningkatan jumlah kasus kekerasan dalam rumah tangga tentunya menjadi keprihatinan tersendiri. Dari data di atas dapat dikatakan bahwa kekerasan rentan terjadi dalam lingkungan rumah tangga. Dalam hal ini korban KDRT tidak hanya menimpa istri atau suami tetapi juga orang-orang yang ada di dalam lingkup rumah tangga. Namun pada umumnya korban KDRT menimpa kaum perempuan yang dianggap sebagai makhluk yang lemah. Sejak dahulu banyak mitos $^{2}$ yang menjadi penyebab ketidakadilan gender, salah satunya adalah laki-laki dianggap bertindak berdasarkan rasional, sedangkan perempuan selalu mendahulukan perasaan. Misalnya perempuan sebagai konco

\footnotetext{
${ }^{2}$ Mitos merupakan sesuatu yang tidak benar, tetapi dipercayai oleh banyak orang, termasuk para ilmuwan. Lihat Jalaluddin Rakhmat, Rekayasa Sosial Reformasi atau Revolusi?. Bandung: Remaja Rosdakarya, 1999, hlm. 4.
} 
wingking atau teman belakang mempunyai fungsi $3 \mathrm{M}$, yaitu masak, macak, manak. Di samping itu juga ada anggapan bahwa tabu bagi lakilaki untuk bekerja di dapur untuk memasak, mencuci, maupun melakukan kegiatan rumah tangga. Dikatakannya jika laki-laki berada di dapur, maka rezekinya akan seret (sulit). ${ }^{3}$

Dalam masyarakat patriarkhi, relasi gender cenderung lebih memberi tempat yang utama bagi laki-laki, sehingga bila dicermati maka dalam banyak bidang kehidupan menempatkan perempuan pada posisi subordinasi. Perempuan seakan menjadi warga kelas dua (second class), dan hal ini menjadi akar ketimpangan relasi gender. Ketimpangan tersebut sering tidak disadari oleh anggota masyarakat dan dianggap sebagai kodrat perempuan. ebagian masyarakat terhegemoni oleh kaidah-kaidah yang ada. Peran dan posisi perempuan yang subordinat dianggap merupakan hal yang wajar.

Selain kesetaraan akan kedudukan, setiap individu juga mempunyai hak asasi. Menurut pasal 1 ayat 1 UU No. 39 Tahun 1999 yang dimaksud dengan hak asasi manusia adalah seperangkat hak yang melekat pada hakikat dan keberadaan manusia sebagai makhluk Tuhan Yang Maha Esa dan merupakan anugerah-Nya yang wajib dihormati, dijunjung tinggi

\footnotetext{
${ }^{3}$ Trisakti Handayani dan Sugiarti, Konsep dan Teknik Penelitian Gender. Malang: UMM Press, 2006, hlm. 10.
}

dan dilindungi oleh negara, hukum dan pemerintah, dan setiap orang demi kehormatan serta perlindungan harkat dan martabat manusia. ${ }^{4}$ Dengan demikian setiap individu berhak atas rasa aman dan tentram serta bebas dari penyiksaan, penghukuman atau perlakuan yang kejam dan tidak manusiawi. Dengan mencermati definisi hak asasi manusia di atas maka dapat dikatakan bahwa KDRT merupakan salah satu bentuk pelanggaran hak asasi manusia (HAM), yang mana korban kekerasan dirampas hak asasinya dan direnggut kebahagiaan serta ketentramannya.

Kekerasan demi kekerasan yang dialami oleh perempuan ternyata meninggalkan dampak traumatik yang sangat berat. Pada umumnya korban merasa cemas, stres, depresi, trauma serta menyalahkan diri sendiri. Sedangkan akibat fisik yang ditimbulkan adalah memar, patah tulang, kerusakan bagian tubuh bahkan kematian. Walaupun perempuan (istri) sebagai korban kekerasan, mereka cenderung bertahan. Hal ini disebabkan karena istri dalam situasi yang terancam, tidak ada tempat berlindung, untuk kepentingan anak, takut dicerca masyarakat karena aib akan ditimpakan pada perempuan, serta

\footnotetext{
${ }^{4}$ Zainuddin Ali, Sosiologi Hukum. Jakarta: Sinar Grafika, 2006, hlm. 90.
} 
alasan demi mempertahankan perkawinan. $^{5}$

Walaupun Indonesia telah meratifikasi Konvensi Penghapusan Segala Bentuk Diskriminasi terhadap Perempuan (CEDAW) dan telah mengesahkan UndangUndang Penghapusan Kekerasan Dalam Rumah Tangga (UU PKDRT) No. 23 Tahun 2004, namun angka kekerasan dalam lingkup domestik tetap saja masih menunjukkan peningkatan dari tahun ke tahun. Padahal dengan Undang-Undang ini diharapkan adanya perlindungan hukum bagi anggota keluarga, khususnya perempuan dari segala tindak kekerasan dalam rumah tangga. Dengan melihat fenomena ini maka peneliti tertarik untuk mengkaji ataupun menggali lebih dalam mengenai faktor-faktor penyebab timbulnya kekerasan dalam rumah tangga, bentukbentuk kekerasan yang dialami oleh survivor serta reaksi survivor terhadap kekerasan yang dialaminya. Kekerasan yang dimaksud adalah kekerasan dalam lingkup rumah tangga.

Penelitian ini mengambil sampel di Lembaga Sahabat Perempuan Magelang, dimana lembaga tersebut merupakan organisasi yang bergerak dalam usaha penghapusan segala bentuk kekerasan terhadap perempuan. Lembaga Sahabat Perempuan merupakan satu-satunya lembaga di Kabupaten Magelang yang memberikan advokasi ataupun

\footnotetext{
${ }^{5}$ Mufidah Ch,. dkk, Haruskah Perempuan dan Anak Dikorbankan?. Malang: Pilar Media, 2006, hlm.13-14.
}

perlindungan bagi korban kekerasan terhadap perempuan. Selain itu, Sahabat Perempuan berusaha untuk mengajak masyarakat di wilayah Kabupaten Magelang untuk berhenti melakukan kekerasan terhadap perempuan.

Adapun tujuan penelitian yaitu: 1) untuk mengetahui faktorfaktor penyebab terjadinya kasus kekerasan dalam rumah tangga pada survivor yang ditangani oleh Lembaga Sahabat Perempuan Magelang, 2) untuk mengetahui bentuk-bentuk kekerasan dalam rumah tangga yang dialami oleh survivor, dan 3) untuk mengetahui reaksi survivor terhadap kekerasan yang dialaminya.

\section{B. Tinjauan Pustaka}

\section{Kedudukan dan Peran Perempuan dalam Keluarga}

Menurut Ki Hadjar

Dewantara, wanita itu dalam pergandaan secara kodrati dinamakan "pemangku turunan", sedangkan orang laki-laki merupakan "pangkal turunan". Seperti halnya seorang suami, perempuan sebagai ibu dalam keluarga mempunyai kedudukan yang sama nilainya, yaitu sebagai kawulo atau abdi, yakni abdi yang mempunyai kedudukan sebagai anggota. Dalam hal ini bapak maupun ibu berhak untuk ikut mengurus dan berkuasa. Sebaliknya, di sini terdapat kewajiban bersama untuk berkorban guna kepentingan umum serta hak untuk ikut melakukan 
kekuasaan untuk keselamatan dan kebahagiaan seluruh keluarga. ${ }^{6}$

Kedudukan perempuan

dalam keluarga antara lain sebagai teman hidup, kekasih dan ibu (pemangku turunan). Yang terpenting fungsi perempuan dalam keluarga adalah sebagai ibu. Seorang ibu adalah pemelihara rumah tangga, dan juga sebagai pengasuh serta pendidikan terhadap anak-anaknya, mulai dari bayi itu dikandungnya sampai usia dewasa, bahkan sampai pada waktu kawinnya, sampai beranak cucu. Oleh karena itu sebagian kalangan dalam masyarakat menyatakan bahwa seorang ibu hanya sekadar perempuan yang tidak jauh sebagai orang yang fungsinya manak (beranak atau berketurunan), macak (bersolek; berdandan), dan masak (memasak).

Dengan melihat kedudukan dan peran perempuan dalam keluarga seperti yang telah dijelaskan di atas, maka dapat dikatakan bahwa posisi perempuan dalam keluarga adalah sangat penting, baik sebagai seorang istri maupun sebagai seorang ibu bagi anak-anaknya. Jadi seorang perempuan memiliki tugas yang sangat mulia dalam menjalankan biduk rumah tangganya. Dengan penuh kesabaran dan keikhlasan, seorang perempuan dapat menjaga eksistensi keluarganya.

\footnotetext{
${ }^{6}$ Hardjito Notopuro, Peranan Wanita dalam Masa Pembangunan Indonesia. Jakarta: Ghalia Indonesia, 1984, hlm. 43-44.
}

\section{Kekerasan dalam Rumah Tangga \\ Kekerasan dalam rumah} tangga menurut UU No. 23 Tahun 2004 adalah setiap perbuatan terhadap seseorang terutama perempuan, yang berakibat timbulnya kesengsaraan atau penderitaan secara fisik, seksual, psikologis dan/atau penelantaran rumah tangga termasuk ancaman untuk melakukan perbuatan, pemaksaan, atau perampasan kemerdekaan secara melawan hukum dalam lingkup rumah tangga. ${ }^{7}$

Pada kasus kekerasan dalam rumah tangga memperlihatkan suatu pola yang menunjukkan siklus kekerasan diantara pasangan suami istri. Siklus ini terdiri dari tiga tahapan (fase) utama, yaitu:

a. Fase ketegangan atau ketegangan yang meningkat Pada tahap ini pelaku kekerasan mulai menyalahkan pasangannya dan menggunakan penganiayaan kecil untuk mengontrol pasangannya. Sebaliknya korban (istri) akan mencoba menyabarkan diri dan timbul perasaan dalam dirinya untuk menyelamatkan rumah tangga.

b. Fase akut atau penganiayaan akut

Pada tahap kedua, ketegangan yang telah meningkat dapat meledak menjadi tindak penganiayaan. Dalam hal ini suami

\footnotetext{
${ }^{7}$ Fathul Djannah, Kekerasan terhadap Istri. Yogyakarta: LKIS, 2007, hlm. 16.
} 
bermaksud untuk memberi pelajaran kepada pasangan, maka timbullah perasaan takut pada istri dan istri mencoba melepaskan rasa marahnya dengan jalan melawan.

c. Keadaan tenang atau fase bulan madu

Setelah terjadi penganiayaan pada istri, terkadang pelaku menyadari dan menyesali tindakannya yang telah melewati batas. Umumnya pelaku akan minta maaf dan berjanji tidak mengulangi penganiayaan lagi. Permintaan maaf suami tersebut membuat istri merasa bahagia dan mempunyai harapan lagi. ${ }^{8}$

Setelah melalui ketiga tahap tersebut, suami istri mulai membentuk kehidupan baru kembali dan melupakan kejadian sebelumnya. Jika tidak muncul kesadaran utuh dari pelaku, maka keadaan ini tidak akan bertahan lama, sampai akhirnya muncul kembali ketegangan, yaitu yang akan berlanjut lagi dari tahap pertama.

Menurut Mufidah $\mathrm{Ch}$, terdapat beberapa kecenderungan orang melakukan dan melanggengkan kekerasan, yaitu: 1) budaya patriarkhi yang menempatkan posisi laki-laki dianggap lebih unggul daripada perempuan, 2) pandangan dan pelabelan negatif (stereotip) yang sangat merugikan, misalnya lakilaki kasar dan perempuan lemah, 3) interpretasi agama yang tidak sesuai

8 Wini Tamtiari, Awig-Awig, Melindungi Perempuan dari Kekerasan Dalam Rumah Tangga?. Yogyakarta: Kerja Sama Ford Foundation dengan Pusat Studi Kependudukan dan Kebijakan UGM, 2005, hlm. 18. dengan nilai-nilai universal agama, misalnya seperti nusyuz, yakni suami boleh memukul istri dengan alasan mendidik, atau ketika istri tidak mau melayani kebutuhan seksual maka suami berhak memukul dan si istri dilaknat oleh malaikat, 4) kekerasan berlangsung justru tumpang tindih dengan legitimasi dan menjadi bagian dari budaya, keluarga, negara, dan praktik di masyarakat, sehingga menjadi bagian kehidupan. ${ }^{9}$

Menurut UU No. 23 Tahun 2004 tentang Penghapusan Kekerasan dalam Rumah Tangga, menyebutkan terdapat empat macam bentuk kekerasan dalam rumah tangga, yaitu sebagai berikut:

a. Kekerasan fisik

Yang dimaksud dengan kekerasan fisik adalah perbuatan yang mengakibatkan rasa sakit, jatuh sakit atau luka berat.

b. Kekerasan psikis

Kekerasan psikis adalah perbuatan yang mengakibatkan ketakutan, hilangnya rasa percaya diri, hilangnya kemampuan untuk bertindak, rasa tidak berdaya, dan/atau penderitaan psikis berat pada seseorang.

c. Kekerasan seksual

Kekerasan seksual adalah setiap perbuatan yang berupa pemaksaan hubungan seksual, pemaksaan hubungan seksual dengan cara tidak wajar dan/atau tidak disukai, pemaksaan hubungan seksual dengan orang lain untuk tujuan komersial dan/atau tujuan tertentu.

\footnotetext{
${ }^{9}$ Mufidah, op. cit, hlm. 7-9.
} 
d. Penelantaran rumah tangga Penelantaran rumah tangga adalah seseorang yang menelantarkan orang dalam lingkup rumah tangganya, padahal menurut hukum yang berlaku baginya atau karena persetujuan atau perjanjian ia wajib memberikan kehidupan, perawatan, atau pemeliharaan kepada orang tersebut. Selain itu, penelantaran juga berlaku bagi setiap orang yang mengakibatkan ketergantungan ekonomi dengan cara membatasi dan/atau melarang untuk bekerja yang layak di dalam atau di luar rumah sehingga korban berada di bawah kendali orang tersebut. ${ }^{10}$

Kekerasan dalam rumah tangga merupakan bentuk pengontrolan terhadap pasangan yang dapat terjadi di setiap masyarakat dan keluarga pada kelas sosial ekonomi manapun, yang terjadi karena adanya anggapan bahwa laki-laki adalah superior dan posisi perempuan adalah inferior. Hal ini menyebabkan suami memiliki hak untuk memaksakan kehendaknya kepada istri karena ia adalah seorang kepala keluarga. Selain itu, anggapan gender bahwa seorang istri seharusnya bekerja di wilayah domestik dan laki-laki bekerja di wilayah publik menyebabkan istri terjebak dalam rutinitas domestik sehingga posisinya termarjinalkan dan

10 Anonim, Sekilas tentang Undang-Undang Penghapusan Kekerasan dalam Rumah Tangga. Tersedia pada http://www.lbhapik.or.id/factsheet.htm. Diakses pada tanggal 23 April 2008. tersubordinasi di dalam rumahnya sendiri.

\section{Survivor}

Survivor merupakan istilah yang digunakan oleh Lembaga Sahabat Perempuan dalam menyebut perempuan korban kekerasan yang ditanganinya. Istilah survivor lebih tepat digunakan karena menunjuk pada kemampuan survive (bertahan) dari para perempuan tersebut. Adapun yang dimaksud dengan korban adalah orang yang menjadi menderita akibat suatu kejadian, perbuatan jahat, dan sebagainya. ${ }^{11}$ Korban ini menerima tindakan di luar perikemanusiaan sehingga mengalami penderitaan, baik fisik maupun nonfisik.

\section{Lembaga Sahabat Perempuan Magelang}

Lembaga Sahabat Perempuan Magelang merupakan sebuah organisasi nirlaba, yaitu organisasi yang tanpa mencari keuntungan. Sahabat Perempuan bergerak dalam usaha penghapusan segala bentuk kekerasan terhadap perempuan. Adapun daerah operasionalnya melingkupi daerah Kabupaten Magelang dan sekitarnya. Berdasarkan klasifikasi awal mula pembentukan lembaga seperti yang telah disebutkan di atas, maka Lembaga Sahabat Perempuan termasuk dalam Emancipatory $N G O^{\prime}$ s. Sesuai bidang geraknya,

\footnotetext{
${ }^{11}$ Tim Penyusun Kamus Pusat Bahasa, Kamus Besar Bahasa Indonesia Edisi Ketiga. Jakarta: Balai Pustaka, 2005, hlm. 595.
} 
Lembaga Sahabat Perempuan memberikan advokasi ataupun perlindungan bagi korban kekerasan terhadap perempuan. Selain itu, Sahabat Perempuan berusaha untuk mengajak masyarakat di wilayah Kabupaten Magelang untuk berhenti melakukan kekerasan terhadap perempuan.

\section{Pembahasan}

1. Faktor-Faktor Terjadinya Kekerasan Dalam Rumah Tangga

Perempuan barang kali tidak lagi memiliki ruang tersisa untuk merasa aman. Lingkup keluarga dianggap sebagai tempat untuk meraih kebahagiaan bagi perempuan justru menjadi tempat penyiksaaan bagi mereka yang mengalami tindak kekerasan oleh suaminya. Di dalam rumah tangga, ketegangan maupun konflik merupakan hal yang sudah biasa terjadi. Perselisihan pendapat, perdebatan, pertengkaran, bahkan memaki merupakan hal yang umum terjadi dalam kehidupan rumah tangga. Kejadian-kejadian seperti itulah yang memicu ketidakharmonisan diantara anggota keluarga. Tentunya tidak ada akibat jika tidak ada sebab yang melatarbelakangi. Begitu juga dengan tindak kekerasan yang terjadi dalam lingkup rumah tangga, yang lebih dikenal dengan sebutan kekerasan dalam rumah tangga (KDRT). Lingkup rumah tangga yang dipandang sebagai lingkungan yang sarat akan kedamaian dan kasih sayang, ternyata juga menyisakan sekelumit kisah yang memilukan dan menimbulkan kepedihan.

Melalui proses pengkajian yang mendalam mengenai wacana kekerasan domestik, yaitu dengan melakukan wawancara dengan korban yang telah mengalami kekerasan dalam rumah tangga (survivor), ternyata terdapat beberapa faktor penyebab yang melatarbelakangi seseorang melakukan kekerasan, diantaranya adalah:

a. Perselingkuhan

Dalam hal ini perselingkuhan yang dimaksud adalah perselingkuhan yang dilakukan oleh suami dengan perempuan lain ataupun suami menikah atau mempunyai istri lagi. Perselingkuhan ini juga menjadi salah satu faktor seseorang melakukan tindak kekerasan dalam rumah tangga. Setelah melakukan wawancara dengan beberapa survivor, pada umumnya mereka telah dikhianati oleh suaminya sendiri. Hal ini dapat dilihat dari sekelumit cerita yang dituturkan oleh para survivor, diantaranya adalah Ibu L, Ibu P, Ibu D, Ibu A dan Ibu I.

Awal

mula ketidakharmonisan rumah tangga Ibu L dikarenakan bahwa suaminya, yaitu Bapak YS melakukan perselingkuhan dengan perempuan lain, seperti penuturannya: "Saya tahu suami saya selingkuh dengan orang di kota $M$, terus jarang 
pulang. Saya tahu sendiri kalau dia selingkuh" ${ }^{12}$

Kisah yang tidak terlalu jauh berbeda dengan Ibu L di atas adalah kisah yang dialami oleh Ibu I, dimana suaminya melakukan pengkhianatan dalam ikatan perkawinannya. Sikap pasrah pun terlihat dari penuturannya sebagai berikut: "Sejak ditinggal, anak pertama masih dalam kandungan usia tujuh bulan. Umur satu tahun bapaknya ke sini lagi. Setelah itu saya mengandung anak kedua namun pada usia tiga bulan suami saya pergi lagi. Suami gluyuran (pergi tanpa ada manfaatnya) ke Kota $\mathrm{Mg}$, katanya jadi sopir tetapi lama-lama tertarik dengan janda Kota $\mathrm{Mg}^{\prime \prime}{ }^{13}$

Faktor perselingkuhan juga menjadi penyebab retaknya hubungan antara Ibu P dan Bapak Sf. Hal ini dapat dilihat dari penuturan Ibu P: "Yang menjadi awal ketidakharmonisan perkawinan adalah perselingkuhan". Kisah yang paling tragis adalah yang dialami oleh Ibu D, dimana suaminya berselingkuh dengan "perempuan nakal", seperti penuturannya:

"Suami saya tidak kasar, sekali menyakiti hati tergoda sama wanita nakal itu yang sudah kelas berbintang, sudah kawin kontrakkawin kontrak kan sudah parah. Mungkin kalau pacaran sama orang kampung mungkin saya bisa terima,

\footnotetext{
${ }^{12}$ Wawancara. Sabtu, 17 Januari 2009, pukul 09.52 .

${ }^{13}$ Wawancara. Sabtu, 17 Januari 2009, pukul
} 13.51 . tapi itu sudah sama wanita yang tidak benar, sering minumminuman, main kartu, ngganja (menggunakan ganja), merokok kan hati saya sudah tidak bisa terima" ${ }^{14}$

Tidak jauh berbeda dengan keadaan yang menimpa survivorsurvivor sebelumnya, dimana mereka "ditikam" dari belakang oleh suami mereka sendiri, Ibu A juga mengalami hal yang serupa. Keutuhan keluarga yang telah dibina bertahun-tahun, akhirnya retak akibat suami mendua dengan perempuan lain. Hal ini dapat dilihat dari penuturan Ibu A berikut:

"Perkawinan mengalami masalah kira-kira anak saya umur delapan bulan. Mulai ketahuannya Aj tiap minggu kok telepon-telepon. Terus saya tanya sama suami, $\mathrm{Aj}$ itu siapa, jawabnya hanya anak kecil di Kota Sm sana. Setelah itu ke sini bawa tas besar. Saya bilang kok ke sini bawa tas besar \& mau menginap lama. Kalau menginap lama ya tidak boleh. Dia mengakunya keponakan suami saya. Kenyataannya tiap hari minggu dia keluar tanpa izin saya. Terus saya tegur, kamu pergi kok tidak izin sama saya, suami saya malah bilang kenapa izin sama kamu karena perginya sama saya. Dulu sebelum ada $\mathrm{Aj}$, suami saya baik, sayang sama saya. Setelah ada perempuan itu sama sekali tidak suka sama saya, serba salah" ${ }^{15}$

\footnotetext{
${ }^{14}$ Wawancara. Sabtu, 24 Januari 2009, pukul 11.25 .

${ }^{15}$ Wawancara. Sabtu, 24 Januari 2009, pukul 10.02 .
} 
Kisah-kisah memilukan di atas merupakan sebuah jeritan kelima perempuan tegar, dimana kesetiaan dalam bingkai pernikahan dipecah oleh sang pemimpin keluarga, yakni suami, dan harus berujung pada sebuah kata perpisahan. Perempuan yang suaminya memiliki hubungan dengan perempuan lain (extra marital relationship) mengalami trauma psikologis karena dua faktor, yaitu perempuan merasa tidak dicintai dan posisinya diambil alih oleh orang lain serta suami menjadi berubah, yang menunjukkan ada sesuatu yang kurang pada dirinya sebagai pasangan dan melihat dirinya sebagai perempuan yang sudah tidak menarik lagi.

\section{b. Masalah ekonomi}

Kepala keluarga (suami) mempunyai tanggung jawab untuk memenuhi kebutuhan rumah tangganya. Nafkah merupakan suatu hak yang dimiliki seorang istri atau anak kepada ayahnya. Namun bila hal itu tidak diindahkan (dilakukan) oleh seorang ayah maka dapat menjadi suatu bentuk kekerasan ekonomi, dimana hal ini dapat menjadi penyebab terjadinya konflik (ketidakharmonisan) dalam keluarga. Terdapat beberapa peristiwa kekerasan yang dialami oleh survivor akibat seorang suami tidak menafkahi istri dan anakanaknya. Hal ini seperti pengalaman $\mathrm{Ibu} \mathrm{L}$ yang ditinggal suaminya pergi ke Sumatra untuk bekerja. Namun hasil dari bekerja itu tidak untuk mencukupi kebutuhan keluarga, malah digunakan untuk bermain judi. Beliau mencoba menguraikan kisahnya seperti yang tertulis dibawah ini:

"Saya mencari nafkah sendiri, mendidik anak sendiri, menyekolahkan sendiri. Suami saya ya pernah mengirim sesuatu, tetapi sama sekali tidak mencukupi, kadang enam bulan sekali, dulu itu memberi Rp 26.000,- pokoknya selama berapa tahun tidak ada sepuluh kali ngirimnya. Misalnya dia kerja, terus saya tanyakan bekerja untuk apa nanti menjawabnya malah marahmarah". 16

Walaupun keadaan ekonomi keluarga Ibu L terhimpit masalah, namun Ibu L tetap mau berusaha untuk menghidupi anaknya. Beliau membuka warung untuk memenuhi kebutuhan sehari-hari tanpa mengandalkan suaminya yang bekerja sebagai buruh (tukang bangunan) di Sumatra.

Kisah yang hampir sama juga diutarakan oleh Ibu S. Sejak perkawinan baru seumur jagung, Bapak $S$ yang tak lain adalah suami Ibu $S$ kurang bertanggung jawab dalam menghidupi keluarganya. Bahkan ekonomi keluarga ditanggung oleh orang tua Ibu S. Meskipun hanya menjual rokok dan minuman di pinggir jalan, orang tua Ibu $S$ rela untuk ikut meringankan beban Ibu S, seperti penuturan Ibu S: "Suami tidak mencukupi, kalau masalah lainnya baik, yang jadi masalah hanya ekonomi, kurang

\footnotetext{
${ }^{16}$ Wawancara. Sabtu, 17 Januari 2009, pukul 09.52 .
} 
tanggung jawab, kalau diarahkan untuk bekerja yang tetap tidak mau. Suami kalau memberi uang saya kadang satu minggu Rp 13.000,kadang Rp 27.000,- kadang kalau tidak bekerja sama sekali tidak memberi" ${ }^{17}$

Selain Ibu L dan Ibu S, masalah ekonomi juga menjadi penyebab kekerasan di keluarga Ibu P. Selain perselingkuhan yang dilakukan oleh suaminya, rumah tangga Ibu P pun mulai retak akibat suami yang tidak mencukupi kebutuhan rumah tangga. Berikut penuturan beliau: "Yang menjadi awal ketidakharmonisan adalah memberi nafkah tidak pasti (sedikit), kerja malas, inginnya kenyang tetapi tidak mau kerja. Dulu sebelum pisah kalau memberi hanya Rp 1.000,- tidak setiap hari, kadang Rp 2.000,- juga tidak setiap hari". ${ }^{18}$

Terkadang laki-laki (suami) tidak merasa bertanggung jawab dalam memberikan nafkah kepada keluarganya. Keluarga Ibu L, Ibu S dan Ibu $\mathrm{P}$ merupakan contoh keluarga yang hidup dalam keterbatasan materi. Ekonomi mereka sangat terhimpit ditambah juga mereka harus menghidupi anaknya. Keterbatasan yang demikian tidak mendorong suami untuk bekerja lebih keras guna kelangsungan hidup keluarga. Oleh karenanya, perempuan (istri) ataupun keluarga pihak istri yang

\footnotetext{
${ }^{17}$ Wawancara. Sabtu, 17 Januari 2009, pukul 11.22.

${ }^{18}$ Wawancara. Sabtu, 17 Januari 2009, pukul 11.54 .
}

mengambil alih peran suami dengan cara berperan ganda, yaitu sebagai pencari nafkah dan juga sebagai ibu rumah tangga. Beban kerja ganda yang harus dipikul perempuan (istri) tersebut merupakan salah satu bentuk manifestasi ketidakadilan gender yang terjadi dalam keluarga.

c. Budaya patriarkhi

Menurut Bhasin, secara harfiah patriarkhi berarti sistem yang menempatkan ayah sebagai penguasa keluarga. Istilah ini kemudian digunakan untuk menjelaskan suatu masyarakat, tempat kaum laki-laki berkuasa atas kaum perempuan dan anak-anak. Hal senada juga dikatakan oleh Usman bahwa perjanjian sosial yang mengatur peranan laki-laki dan perempuan dibingkai oleh sebuah sistem patriarchal, yang lebih banyak menempatkan laki-laki pada posisi kunci atau pada peranan yang lebih dominan. Sistem tersebut kemudian menempatkan status dan peranan perempuan di bawah perwalian laki-laki. ${ }^{19}$

Dalam masyarakat patriarkhi, relasi gender cenderung lebih memberi tempat yang utama pada laki-laki, sehingga bila dicermati secara teliti maka dalam banyak bidang kehidupan menempatkan perempuan pada posisi subordinasi. Laki-laki dianggap lebih berkuasa dan di atas segalanya dari seorang

\footnotetext{
${ }^{19}$ Sri Meiyanti, Kekerasan terhadap Perempuan dalam Rumah Tangga. Yogyakarta: Kerja Sama Ford Foundation dengan Pusat Penelitian Kependudukan UGM, 1999, hlm. 7.
} 
$\begin{array}{lcr}\text { perempuan. } & \text { Dalam } & \text { lingkup } \\ \text { domestik, } & \text { anggapan } & \text { ini } \\ \text { menimbulkan } & \text { sikap } & \text { adanya } \\ \text { ketergatungan } & \text { perempuan } & \text { (istri) }\end{array}$ kepada suami serta perempuan merasa dirinya lemah dan tidak berdaya. Ibu $S$ misalnya, dalam kehidupan rumah tangganya, suami tetap yang lebih dominan dalam memegang kendali keluarga. Beliau menuturkan:

"Dominasi dalam mengatur hidup lingkungan, seumpama gotong royong sama tetangga, belanja rumah tangga, kebutuhan rumah tangga. Saya menanggapinya ya baik-baik saja. Sebagai kepala keluarga tetap suami yang menjadi panutan, saya hanya sebagai peratara, ibaratnya saya di bawah kekuasaan suami. Saya jadi orang menerima, sekarang demi anak, anak bisa bersama bapaknya". ${ }^{20}$

Hal serupa juga dialami oleh Ibu $\mathrm{T}$ yang dalam kesehariannya bekerja sebagai perawat di salah satu Puskesmas di Kota Mg. Ibu T menyampaikan bahwa:

"Yang lebih dominan dalam memegang kendali keluarga adalah suami, dalam hal segalanya, misalnya hari itu saya harus melakukan apa, setelah saya pulang kerja saya harus melakukan apa, saya ingin mengambil anak-anak karena anak-anak saya titipkan tidak boleh saya harus kerja. Saya punya uang, uang harus saya apakan, saya nurut sama dia, saya harus pergi ke mana juga harus bilang ke dia". ${ }^{21}$

\footnotetext{
${ }^{20}$ Wawancara. Sabtu, 17 Januari 2009, pukul 11.22 .

${ }^{21}$ Wawancara. Sabtu, 24 Januari 2009, pukul 14.43 .
}

Apa yang dialami Ibu S dan Ibu $\mathrm{T}$ tersebut merupakan contoh sah dimana seorang perempuan yang tidak mampu keluar dari jaring kekuasan suami. Keadaan demikian membuat perempuan selalu berlindung di bawah ketiak suami, dianggap sebagai bawahan dan warga kelas dua.

\section{d. Campur tangan pihak ketiga Campur tangan anggota} keluarga dari pihak suami dalam penelitian ini merupakan salah satu penyebab timbulnya kekerasan antara suami istri. Peristiwa semacam ini dialami oleh Ibu D yang pernah tinggal satu rumah dengan mertuanya di Kota Tg. Menurutnya:

"Saya dengan suami cocok, tetapi habis kita nikah pihak keluarga terlalu mencampuri urusan keluarga saya, jadi saya tidak mau kalau dicampuri sama kakaknya, orang tuanya, karena menghina saya. Dikatakannya kowe kere (kamu miskin), kan menyakitkan hati. Selain itu kalau suami pas bantu-bantu, pihak keluarga tidak boleh. Tidak usah dibantu, pihak istrimu karena tidak pernah weh-weh (memberi)". 22

Hal serupa juga pernah dialami oleh Ibu $\mathrm{T}$, dimana campur tangan pihak keluarga suami menjadi penyebab konflik dalam rumah tangganya. Peristiwa itu terjadi saat mereka tinggal di rumah orang tua Bapak YS (suami Ibu T), seperti penuturannya berikut ini: "Mungkin karena saya orangnya

\footnotetext{
${ }^{22}$ Wawancara. Sabtu, 17 Januari 2009, pukul 13.51 .
} 
tidak manut (tidak patuh) karena beda pendapat tadi mereka (keluarga suami) menganggap saya berani sama laki-laki". ${ }^{23}$

Kasus-kasus di atas menunjukkan bahwa keberadaan anggota keluarga lain, khususnya dari pihak suami, dapat menyebabkan terjadinya kekerasan terhadap istri dan bukan sebaliknya mencegah suami untuk bertindak kekerasan terhadap istri.

e. Bermain judi

Judi merupakan sesuatu yang dilarang, baik oleh hukum maupun agama. Bermain judi bagi sebagian kalangan memang sesuatu yang mengasyikkan, kadang malah membuat segalanya menjadi lupa. Seperti yang dialami oleh Ibu I yang suaminya hobi mabuk dan bermain judi. Awal ketidakharmonisan keluarga Ibu I dimulai saat orang tua Ibu I membelikan menantunya, yang tak lain adalah suami Ibu I sebuah andong (dokar). Bermaksud untuk menghidupi istri dan anakanaknya, namun pada kenyataannya uang hasil jerih payahnya digunakan untuk berjudi dan minum minuman keras. Alhasil orang tua Ibu I pun kecewa. Setelah mengetahui kejadian itu, suami Ibu I tersebut meninggalkan keluarganya dan beralih ke perempuan lain. Bermula dari terlalu menyukai hobinya yaitu berjudi dan minum-minuman keras, serta berlanjut dengan penelantaran keluarga, akhirnya rumah tangga

\footnotetext{
${ }^{23}$ Wawancara. Sabtu, 24 Januari 2009, pukul 14.43 .
}

Ibu I berujung pada perpisahan. Suami Ibu I pergi meninggalkan istri serta kedua anaknya dan memilih seorang janda yang sudah mempunyai dua orang anak. Namun perpisahan ini hanya sebatas perpisahan, dan belum ada kata cerai diantara mereka.

\section{f. Perbedaan prinsip} Prinsip menurut Kamus Besar Bahasa Indonesia merupakan asas (kebenaran yang menjadi pokok dasar berpikir, bertindak, dan sebagainya) ataupun dasar. ${ }^{24}$ Seseorang yang telah memiliki dasar dalam berperilaku maka akan selalu berpegang pada prinsip yang diyakininya. Apabila ada orang lain yang mencoba untuk menggoyahkan prinsip tersebut maka seseorang akan tersinggung dan tidak terima. Tidak terkecuali hubungan antara suami istri dalam rumah tangga. Walaupun mereka telah menyatu dalam ikatan pernikahan, namun tidak dapat dipungkiri jika keduanya memiliki prinsip yang berbeda. Perbedaan prinsip inilah yang dapat menjadikan pertengkaran (kekerasan dalam rumah tangga), seperti yang dialami Ibu $\mathrm{T}$ berikut ini:

"Pokoknya semua pendapat saya tidak ada yang sama dengan dia (suami) dan semua ditentang. Dari semua masalah, saya yang salah. Bagi saya dalam rumah tangga tidak harus satu orang bisa

\footnotetext{
${ }^{24}$ Tim Penyusun Kamus Pusat Bahasa, op. cit, hlm. 896.
} 
memutuskan masalah. Kita kan harus ada musyawarah, tukar pendapat dulu bagaimana baiknya, itu tidak. Kamu besok harus ke sana padahal saya harus kerja. Kamu harus ke sana dulu tidak boleh kerja.

Bagaimana pertanggungjawaban saya dengan pekerjaan saya, ya saya kan tetap ngeyel (tidak mau kalah), yang pertama kan pekerjaan saya dulu. Dia tidak mau tahu saya, tahunya dia cuma aku, cuma aku, tidak mau tahu orang lain" ${ }^{25}$

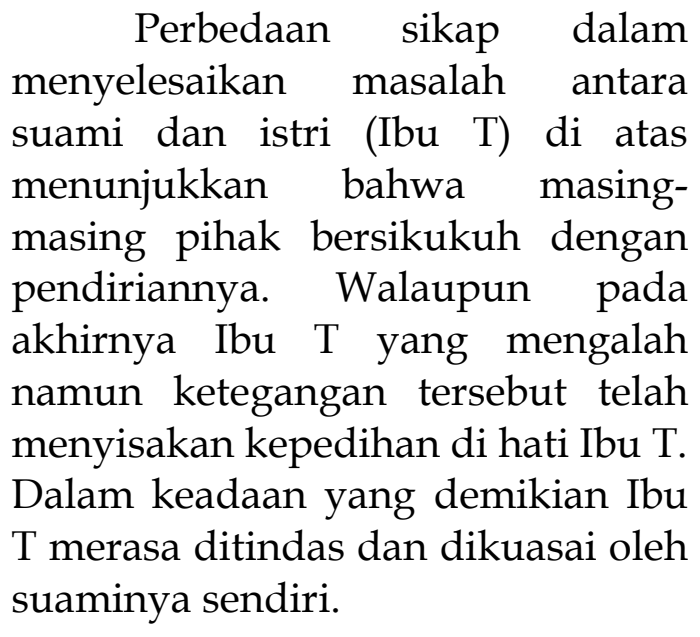

\section{Bentuk-Bentuk Kekerasan Dalam Rumah Tangga}

Setiap informan (survivor) dalam penelitian ini pernah mengalami kekerasan, bahkan mereka tidak hanya mengalami satu jenis kekerasan. Kekerasan yang dialami para istri dalam penelitian ini adalah kekerasan fisik, kekerasan psikis, dan penelantaran rumah tangga (ekonomi).

a. Kekerasan fisik

Kekerasan fisik merupakan perbuatan yang mengakibatkan rasa

\footnotetext{
${ }^{25}$ Wawancara. Sabtu, 24 Januari 2009, pukul 14.43 .
}

sakit, jatuh sakit atau luka berat. Terdapat beberapa jenis kekerasan yang dapat digolongkan sebagai kekerasan fisik, antara lain adalah dipukul, dilempar dengan barang, dijambak rambutnya, ditendang, dan sebagainya. Bentuk kekerasan seperti ini juga dialami oleh para survivor yang bersedia meluangkan waktunya untuk berbagi pengalaman dengan peneliti. Kisah seorang istri yang bernama Ibu L sering mendapat serangan fisik dari suaminya sendiri. Seperti yang dikatakan Ibu L dengan peneliti: "Menampar itu pasti, yang menjadi hafalan menampar itu. Menampar, menjambak sudah hobi sedikitsedikit menampar, menjambak" ${ }^{26}$

Apa yang dilakukan suami Ibu $\mathrm{L}$ dan Ibu $\mathrm{T}$ sudah terlewat batas dan tidak mengindahkan norma yang ada. Apalagi peneliti melihat gigi Ibu L bagian depan beberapa sudah tanggal akibat perlakuan kejam suaminya. Kekerasan yang diekspresikan dengan kekuatan fisik memang menimbulkan luka, baik luka yang tampak (seperti memar, cacat tubuh) maupun luka yang tidak tampak, yaitu luka yang terpendam dalam hati Luka dalam hati tersebut dapat menimbulkan korban kekerasan mengalami trauma atau gangguan psikologis akibat suatu perlakuan yang tidak manusiawi.

b. Kekerasan psikis

Kekerasan psikis adalah perbuatan yang mengakibatkan ketakutan, hilangnya rasa percaya diri, hilangnya kemampuan untuk

\footnotetext{
${ }^{26}$ Wawancara. Sabtu, 17 Januari 2009, pukul 09.52 .
} 
bertindak, rasa tidak berdaya, dan/atau penderitaan psikis berat pada seseorang. Pada umumnya survivor yang diwawancarai oleh peneliti mendapat perlakuan yang dapat meruntuhkan harga diri, seperti caci maki, kata-kata kasar, ancaman (ancaman dipenjara, dibunuh), dan tuduhan. Ibu S, salah satu survivor yang bercerita tentang masa lalunya mengaku pernah mendapat ucapan-ucapan yang kasar dari suaminya sendiri. Dikatakannya bahwa "Kalau bicara dengan tetangga, mencukupi semuanya, tetapi kenyataannya tidak, itu berarti dia kan menipu saya. Sudah pernah saya difitnah, kata suami, saya menyuruhnya untuk menjual rumah padahal saya tidak pernah, terus diomongkan dengan teman, tetangga sama saudara-saudaranya" ${ }^{27}$

Ibu $T$ juga mengalami kekerasan yang serupa, yaitu selain mendapat perlakuan fisik (ditempeleng dan diinjak-injak), beliau juga mendapat ancaman dari pihak suaminya. Beliau menceritakan bahwa: "Dia terus mengancam, awas kalau ngomong sama orang lain, kamu akan mendapat yang lebih parah lagi" ${ }^{28}$

Kekerasan psikis merupakan kekerasan yang paling menyakitkan bagi para istri (survivor). Hal ini dikarenakan mereka menjadi tertekan dan tidak berdaya dalam menghadapi sikap suaminya yang

\footnotetext{
${ }^{27}$ Wawancara. Sabtu, 17 Januari 2009, pukul 11.22.

${ }^{28}$ Wawancara. Sabtu, 24 Januari 2009, pukul 14.43 .
}

begitu kejamnya. Kekerasan psikis juga menimbulkan luka yang sangat sulit untuk disembuhkan, karena adanya perasaan takut dan trauma dalam diri korban. Trauma tersebut akan menyebabkan seseorang mengalami gangguan psikologis yang menyebabkan dirinya malu dan jika suatu saat kekerasan terjadi lagi padanya maka kejiwaannya akan terganggu.

c. Penelantaran rumah tangga (ekonomi)

Penelantaran rumah tangga adalah seseorang yang menelantarkan orang dalam lingkup rumah tangganya, padahal menurut hukum yang berlaku baginya ia wajib memberikan kehidupan, perawatan, atau pemeliharaan kepada orang tersebut. Selain itu, penelantaran rumah tangga juga berlaku bagi setiap orang yang mengakibatkan ketergantungan ekonomi dengan cara membatasi dan/atau melarang untuk bekerja yang layak di dalam atau di luar rumah sehingga korban berada di bawah kendali orang tersebut. Bentuk kekerasan berupa penelantaran rumah tangga terjadi pada Ibu L, dimana suaminya tidak bertanggung jawab dalam mencari nafkah, dikatakannya bahwa:

"Saya cari nafkah sendiri, mendidik anak sendiri, menyekolahkan sendiri. Suami hanya bekerja sesuka hati, untuk kesenangan sendiri, untuk judi, mabuk juga. Pernah mengirim sesuatu tetapi tidak mencukupi, kadang enam bulan sekali, dulu ngasih Rp 26.000,- pokoknya selama 
berapa tahun tidak ada sepuluh kali ngirimnya. Kalau pulang tidak membawa uang, pulang hanya menengok saja, tidak meninggalkan uang kira-kira cukup buat hidup tidak, pulang ya hanya sekadar pulang". ${ }^{29}$

\section{Reaksi Survivor terhadap Kekerasan yang Dialaminya}

Adanya kekerasan dalam rumah tangga yang dialami oleh seorang istri melahirkan sikap diam ataupun melawan terhadap serangan ataupun kekerasan yang dilakukan oleh suami. Secara garis besar dalam penelitian ini terdapat tiga dari tujuh survivor yang memilih diam atas perlakuan kasar suami terhadapnya. Tiga orang survivor yang memilih diam tersebut adalah Ibu L, Ibu I dan Ibu T. Dalam pembicaraannya dengan peneliti, Ibu L lebih memilih diam dikarenakan beliau tidak mau kalau malah terjadi pertengkaran (adu mulut), menurutnya sikap diam adalah lebih baik walaupun hati terasa sakit.

Ungkapan tersebut dapat dilihat dari penuturan beliau: "Ya dulu saya banyak diamnya, masalahnya kalau saya tidak diam malah mesti ndadine (marahnya) tambah parah. Sampai sekarang, sampai akhir kejadian ini saya hanya diam, diam dan diam. Dulu saya cuma diam, tetangga tidak ada yang tahu, tahunya baik, rukun padahal di rumah tidak pernah bertegur sapa". ${ }^{30}$ Walaupun

\footnotetext{
${ }^{29}$ Wawancara. Sabtu, 17 Januari 2009, pukul 09.52 .

${ }^{30}$ Wawancara. Sabtu, 17 Januari 2009, pukul 09.52 .
}

perlakuan suami Ibu L telah menyakiti hati Ibu L, namun beliau tidak pernah menyatakan penyesalannya. Setelah berulang kali menerima perlakuan kasar dari suami maka Ibu L meminta perlindungan ke pejabat setempat, seperti penuturannya:

"Kalau dulu saya cuma bilang saudara, adik saya begitu. Dulu pernah parah juga terus saya memanggil kepala dusun terus suami saya dinasehati, katanya janji tidak mau mengulang, tetapi ya kejadian lagi malah lebih parah. Terus pas kejadian saya langsung telepon kantor polisi. Kebetulan ada teman saya yang polisi menyarankan untuk ke Sahabat Perempuan". 31

Selain bersikap diam, terdapat empat survivor yang bersikap melawan atas perlakuan kasar yang dilakukan oleh suami mereka. Sikap melawan tersebut ditunjukkan oleh Ibu S, Ibu P, Ibu D, dan Ibu A. Ibu $S$ yang mengalami kekerasan ekonomi (penelantaran rumah tangga), berani bersikap melawan jika suami bertindak yang menyakitkan kepada dirinya. Hal ini dilakukan Ibu $S$ untuk membela haknya, yaitu sebagai seorang istri dan juga sebagai seorang ibu. Terkadang suami meminta maaf atas kesalahan yang dibuatnya, sampai-sampai orang tua Ibu $S$ ikut masalah, seperti penuturannya:

"Orang tua saya bilang kalau tidak bisa mencukupi anak istri ya sudah sendiri-sendiri saja. Dia merasa salah terus minta maaf tetapi kalau masalah sepele hanya

${ }^{31}$ Ibid. 
saya sama bapaknya kalau salah ya tidak pernah meminta maaf". ${ }^{32}$

Dengan keadaan yang demikian Ibu $S$ akan mengambil jalan hidup sendiri jika suami terlewat batas. Sikap perlawanan juga ditunjukkan oleh Ibu P terhadap sikap suami yang telah melakukan kekerasan terhadap dirinya dan keluarganya. Hal ini seperti penuturan beliau:

"Kalau saya melawan, terus saya lapor sama ayah saya. Setelah itu suami pergi dari rumah, masalahnya sama mertua berani, sama saya juga berani. Sebelum peristiwa itu dia pulang ke tempat orang tuanya. Tidak mau pulang ke sini. Penyesalan pun tidak ada, perselingkuhan malah diteruskan". 33

Setelah peristiwa tersebut akhirnya Ibu $\mathrm{P}$ berencana untuk menggugat cerai suaminya, namun sebelum menggugat cerai, terlebih dahulu Ibu P melakukan konsultasi dengan konselor Sahabat Perempuan.

Dari paparan kisah para survivor di atas juga dapat dikaji bahwa dalam menghadapi kekerasan, survivor juga mencari cara agar kekerasan yang terjadi tidak pernah menghampiri dirinya lagi. Adapun cara yang diambil oleh para survivor adalah dengan melakukan konsultasi dengan konselor Sahabat Perempuan, mencari perlindungan aparat

\footnotetext{
${ }^{32}$ Wawancara. Sabtu, 17 Januari 2009, pukul 11.22.

${ }^{33}$ Wawancara. Sabtu, 17 Januari 2009, pukul 11.54 .
}

setempat ataupun dengan mengorbankan dirinya untuk bercerai dengan suaminya, bahkan salah satu survivor (Ibu A) merelakan suaminya untuk menikah kembali dengan perempuan lain. Cara-cara tersebut diambil oleh survivor karena mereka menerima perlakuan kasar dari suami tidak hanya sekali, dan yang lebih disayangkan bahwa dengan sikap istri yang diam ataupun melawan, suami tetap tidak menyatakan penyesalannya, malah kekerasan terus dilakukan.

\section{Kesimpulan}

Kekerasan dalam rumah tangga merupakan suatu permasalahan yang telah menjadi isu global. Hal ini dikarenakan kekerasan dalam lingkup domestik telah mengesampingkan kedudukan dan peran perempuan dalam keluarga. Adanya bias gender dalam kehidupan keluarga menjadikan perempuan tersubordinasi, termarginalisasi, mengalami beban kerja ganda, serta mengalami kekerasan. Dalam hal ini kekerasan telah merenggut hak-hak perempuan, diantaranya adalah hak untuk memiliki rasa nyaman, bebas dari ketakutan dan perlakuan kejam. Fenomena kekerasan dalam lingkup rumah tangga tak ubahnya fenomena gunung es, dimana kenyataan yang tampak tidak sebanyak yang terjadi di lapangan. Data menunjukkan bahwa dari tahun ke tahun angka kekerasan, terutama dalam lingkup domestik selalu mengalami peningkatan. 
Melalui penelitian yang mengambil sampel di Lembaga Sahabat Perempuan Magelang diketemukan bahwa terdapat beberapa faktor yang menjadi penyebab terjadinya kekerasan dalam rumah tangga, yaitu perselingkuhan, masalah ekonomi, campur tangan pihak ketiga, bermain judi, budaya patriarkhi, serta perbedaan prinsip. Faktor perselingkuhan merupakan faktor utama yang menyebabkan kekerasan dalam rumah tangga. Adapun bentuk-bentuk kekerasan yang dialami oleh survivor adalah kekerasan fisik, kekerasan psikis, dan penelantaran rumah tangga (ekonomi).

Dalam menghadapi sikap suami yang demikian kerasnya maka pada umumnya survivor memilih untuk diam ataupun melawan. Sikap yang dipilih survivor ini merupakan suatu keputusan yang dinilai tepat. Sikap diam diambil untuk meredakan ketegangan yang sedang berlangsung, serta untuk menjaga kehormatan keluarga karena memperbincangkan masalah keluarga kepada orang lain merupakan aib, sedangkan survivor memilih melawan dikarenakan mereka tidak mau diinjak-injak harga dirinya oleh suami serta membuktikan bahwa ia bukan makhluk yang lemah. Dengan demikian dapat dikatakan bahwa masih relevannya teori konflik, teori fungsionalisme struktural dan teori feminisme dengan kenyataan yang ada di masyarakat, yakni dalam mengkaji masalah kekerasan dalam rumah tangga.

\section{Daftar Pustaka}

Fathul Djannah, Kekerasan terhadap Istri. Yogyakarta: LKIS, 2007.

Hardjito Notopuro, Peranan Wanita dalam Masa Pembangunan Indonesia. Jakarta: Ghalia Indonesia, 1984.

Jalaluddin Rakhmat, Rekayasa Sosial Reformasi atau Revolusi?. Bandung: Remaja Rosdakarya, 1999.

Mufidah Ch,. dkk, Haruskah Perempuan dan Anak Dikorbankan?. Malang: Pilar Media, 2006

Sri Meiyanti, Kekerasan terhadap Perempuan dalam Rumah Tangga. Yogyakarta: Kerja Sama Ford Foundation dengan Pusat Penelitian Kependudukan UGM, 1999.

Tim Penyusun Kamus Pusat Bahasa, Kamus Besar Bahasa Indonesia Edisi Ketiga. Jakarta: Balai Pustaka, 2005.

Trisakti Handayani dan Sugiarti, Konsep dan Teknik Penelitian Gender. Malang: UMM Press, 2006.

Wini Tamtiari, Awig-Awig, Melindungi Perempuan dari Kekerasan Dalam Rumah Tangga?. Yogyakarta: Kerja Sama Ford Foundation dengan Pusat Studi Kependudukan dan Kebijakan UGM, 2005.

Zainuddin Ali, Sosiologi Hukum. Jakarta: Sinar Grafika, 2006. 